\title{
Feulgen-hydrolysis profiles in cells exfoliated from the cervix uteri: a potential aid in the diagnosis of malignancy
}

\author{
JA MILlETT, OAN HUSAIN, L BITENSKY,* J CHAYEN* \\ From the Cytology Department, Charing Cross Hospital, London W6 8RF and the \\ * Division of Cellular Biology, Kennedy Institute of Rheumatology, London W6 7DW
}

SUMMARY By varying the time of hydrolysis for the Feulgen reaction, done under conditions that protect the backbone of the DNA, it is possible to distinguish three species of DNA that are characterised by their lability to acid hydrolysis. The most labile DNA was found, in greatest proportions, in malignant cells; this may be helpful in diagnostic cytology. The fact that the cytologically normal cells, in grade V smears, also show this labile DNA may well facilitate cytological screening even in those smears that contain very few neoplastic cells.

In the search for functional tests to complement the conventional cytological screening for cervical and endometrial cancers ${ }^{12}$ our interest has turned to the nature of chromatin in the "malignant" cell nucleus.

It is now known that chromatin is a complex of DNA with various proteins. The degree of protein-binding is thought to be dependent on a number of factors including the level of metabolic activity in the cell and the stage of the cell in the mitotic cycle. ${ }^{34}$ The possibility of distinguishing these different "species" of DNA by their lability to acid hydrolysis and subsequent Feulgen staining has been suggested..$^{5-8}$

The Feulgen reaction ${ }^{9}$ depends upon the prior hydrolysis of DNA by acid to unmask aldehyde groups in the DNA, which in turn react with Schiff's base to give an intensely coloured dye. Prolonged treatment with acid will cleave the DNA-backbone, rendering the DNA soluble. The rate at which DNA is hydrolysed depends on the degree of binding and therefore on the compactness of the DNA within the chromatin. ${ }^{10-12}$

Feulgen hydrolysis profiles of cells in which one might expect to find more transcriptionally-active DNA - for example, embryonic cells, ${ }^{5}$ viral infected cells, ${ }^{7}$ and malignant cells, ${ }^{6}{ }^{13}$ show evidence of more acid-labile DNA.

The possibility of using DNA hydrolysis profiles to distinguish between malignant and non-malignant abnormalities of the cervix has been investigated. To facilitate these studies, we found it useful to hydrolyse at lower temperatures than those used in previous

Accepted for publication 23 July 1981 studies because, under these conditions, the DNA backbone is cleaved more slowly. ${ }^{14}$ For this reason, hydrolysis with $5 \mathrm{~N}$ hydrochloric acid at room temperature ${ }^{15}$ has been used.

\section{Material and methods}

Cervical and vaginal irrigation samples were obtained with a bellows cytopipette containing normal physiological saline. The cytopipette was manufactured by Lerner laboratories to a design by OAN Husain and $J$ Ladinsky which affords an $8 \mathrm{ml}$ wash of the cervix and vagina through four apertures in its bulbous tip in contrast to the $2 \mathrm{ml}$ output of the Davis pipette ${ }^{16}$ (Fig. 1).

After centrifugation ( $300 \mathrm{~g}$ for $5 \mathrm{~min}$ ) a drop of the cell deposit was placed on a glass slide which had been coated with bovine albumin; the cells were smeared over the surface and left to dry in air.

Samples were collected from 19 benign cases (modified Papanicolaou grades ${ }^{2}$ I and II), nine patients with moderate to severe dysplasia (grade III), 19 patients with obvious carcinoma-in-situ (grade IV) and 10 patients with invasive carcinoma of the cervix (grade V). Routine cervical smears, collected at the same time as the research samples, were stained by the Papanicolaou ${ }^{17}$ method and used to establish the cytological grades.

For all patients in grade $\mathrm{V}$ and all but three of grade IV, there was also histological confirmation.

METHODS

The smears were fixed in acetic-alcohol (25:75) for 10 345 


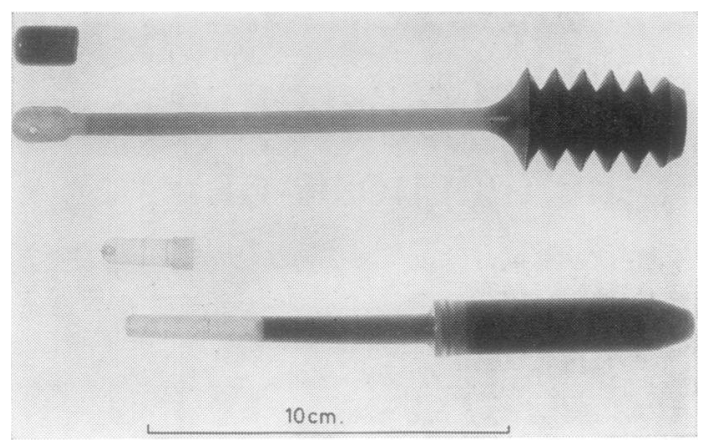

Fig. 1 Bellows cytopipette. The bellows action permits full evacuation of the $8.5 \mathrm{ml}$ contents through the four apertures compared with the Davis pipette (below) with a $2 \mathrm{ml}$ full squeeze output through one aperture where a full salvage return never occurs.

min and then left to dry in air. They were then dipped briefly in $1 \mathrm{~N}$ hydrochloric acid at room temperature $\left(20^{\circ} \mathrm{C}\right)$ and transferred to $5 \mathrm{~N}$ hydrochloric acid, again at room temperature, for various periods of time $(5,10,15 \mathrm{~min}$; then at ten-minute intervals up to $70 \mathrm{~min}$ ). At each time-interval, one slide was removed, rinsed in $1 \mathrm{~N}$ hydrochloric acid and immersed, in the dark, in Schiff's reagent for $1 \mathrm{~h}$. It was then washed in three changes of bisulphite-water $(2: 1 \mathrm{vol} / \mathrm{vol}, 0.5 \%$ solution of potassium metabisulphite to $1 \mathrm{~N}$ hydrochloric acid). After rinsing in distilled water, the cells were dehydrated in $70 \%$ absolute alcohol, cleared in xylene and mounted in Styrolite.

In general, 20 structurally normal nuclei and, when possible, up to 20 abnormal nuclei were measured from each slide. Abnormal nuclei were chosen by their malignant characteristics - that is, large size and irregular chromatin pattern. The measurements were made by means of a Vickers M85 scanning and integrating microdensitometer at $550 \mathrm{~nm}$, with a $\times 40$ objective and a scanning spot-size of $0.5 \mu \mathrm{m}$ diameter in the plane of the specimen. For all measurements a mask which had a diameter of $20 \mu \mathrm{m}$ was used. This was sufficiently large to encompass the larger malignant nuclei; the clear field around the smaller normal nuclei would not introduce any error. ${ }^{18}$ The results were expressed as the relative absorption, as recorded by the microdensitometer.

Student's $t$ test was used to analyse the results.

\section{Results}

The Feulgen-hydrolysis profiles of the amount of Feulgen reaction measurable after each period of hydrolysis in cells from grades I and II showed two main peaks (Fig. 2). The first was maximal at about

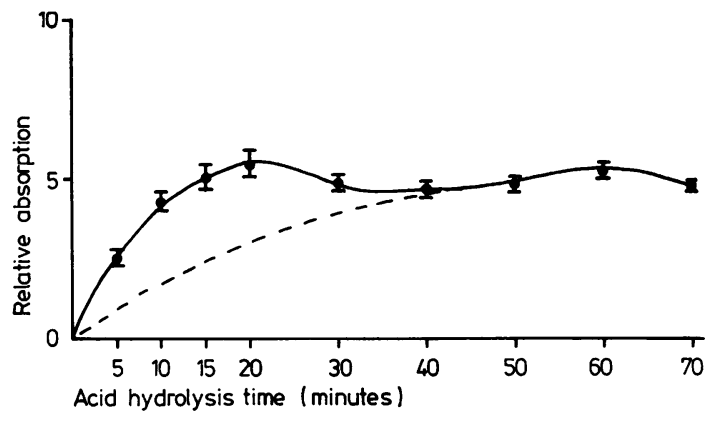

Fig. 2 Feulgen hydrolysis profile obtained from cells from a benign (grade I) sample. The bars represent the standard error of the mean. The broken line indicates how the area occupied by each peak has been apportioned.

$20 \mathrm{~min}$ of hydrolysis and the second was maximal at about $60 \mathrm{~min}$. (These we have called peaks 2 and 3 respectively.) In some, a small deviation from the smooth graph was present after $5 \mathrm{~min}$ of hydrolysis. In contrast, in the graphs derived from the malignant cells there was a prominent peak in the profile which was maximal after 5 min of hydrolysis-peak 1 (Fig. $3 a)$, as well as clear peaks 2 and 3 .

These three features were also apparent, to a lesser degree, in the cytologically normal cells in the same smears (Fig. 3b).

The hydrolysis profiles from grade IV specimens varied, some resembling malignant samples and others approximating to the non-malignant cells.

\section{REPRODUCIBILITY}

To find how reproducible the method was at a given hydrolysis time, five slides were prepared from each of four different normal samples. They were hydrolysed for the same time, stained and then measured. The coefficient of variation for each of the four samples was $5 \%, 5 \cdot 8 \%, 4 \cdot 7 \%$, and $6.9 \%$.

\section{STATISTICAL SIGNIFICANCE OF PEAKS}

The significance of the peaks obtained was tested by Student's $t$ test on the cell populations making up the "peaks" and the "troughs." For example (see Fig. $3 a)$, the mean value of the amount of Feulgen stain in the cells after 10 min hydrolysis, that is peak 1 , was calculated as 10.1 units with a standard deviation of \pm 3.38 and a standard error of the mean of 0.78 . The mean value for the cells after $15 \mathrm{~min}$ hydrolysis, however, had fallen to 7.9 units with a standard deviation of \pm 2.78 and standard error of the mean of 0.72 . The difference between these values in a Student's $t$ test was just significant $(p<0.025)$. The mean value for the Feulgen stain at the next peak, after $20 \mathrm{~min}$ hydrolysis, was 12.7 with a standard deviation of \pm 3.47 


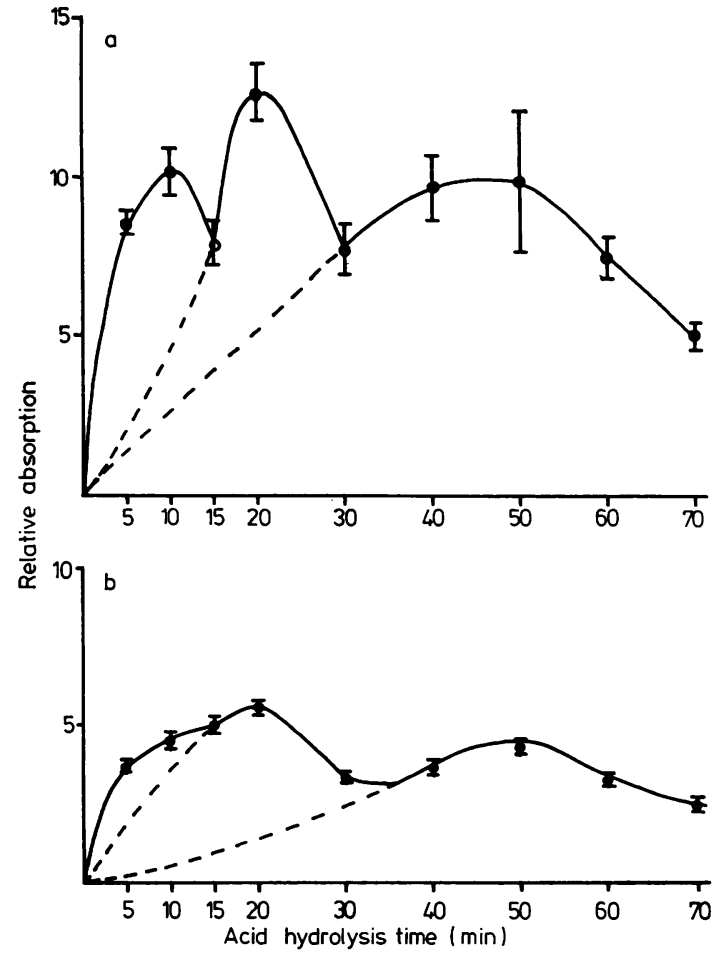

Fig. 3 Feulgen hydrolysis profiles obtained from (a) cytologically positive cells and (b) cytologically normal cells in a smear from an invasive squamous cell carcinoma of the cervix. Positive cells are those showing morphological criteria of malignancy-for example, enlarged nuclei with an irregular chromatin pattern. The broken lines demarcate the areas occupied by peaks 1,2 and 3 respectively from the $y$ axis.

and standard error of the mean 0.93 . This was significantly different from the 15 min value of $7.9 \pm 2.78$ (p $<0.001$ ). Table 1 shows the results of other $t$ tests. As a general rule, a difference in the mean value

Table 1 The significance ( $p$ ) of different percentage changes in the mean absorption values of "peaks" and "troughs" on the Feulgen hydrolysis profiles

\begin{tabular}{lrcl}
\hline Mean 1 & Mean 2 & $\%$ difference & $p$ \\
\hline 10.13 & 7.90 & 22 & $<0.025$ \\
7.90 & 12.69 & 37 & $<0.001$ \\
3.99 & 1.99 & 50 & $<0.001$ \\
1.99 & 3.75 & 47 & $<0.005$ \\
4.21 & 3.03 & 28 & $<0.001$ \\
6.29 & 5.49 & 13 & $<0.001$ \\
4.75 & 4.33 & 9 & NS \\
4.98 & 4.29 & 14 & NS \\
7.63 & 7.37 & 3 & NS \\
\hline
\end{tabular}

Level of significance determined by Student's $t$ test. NS $=$ not significant. of the stain intensity of $15 \%$ or more was required for the peak to be statistically significant.

Area under peaks

Normal $v$ malignant cells The area occupied by each peak was measured by planimetry of the curves produced by extrapolation (Fig. 3a). This method is frequently used in spectroscopic analysis of partiallysuperimposed absorption curves. The value for the area was then expressed as a percentage of the total Feulgen stain (total area of the profile).

Initially the combined areas of peaks 1 and 2 were calculated and the results for the normal grades were compared with those from the positive cells in the malignant cases. The mean value for the 19 specimens from the benign grades was $14 \cdot 1$ units with a standard error of $\pm 1 \cdot 25$; the equivalent value from grade $V$ cases was $29 \cdot 2 \pm 3 \cdot 15$ (Table 2). The difference was highly significant in Student's $t$ test $(\mathrm{p}<0.001)$.

Table 2 Cytologically malignant cells, from grade $V$ smears, compared with normal cells (from benign cases): the statistical evaluation of the proportional areas occupied by the first two peaks considered together or individually

\begin{tabular}{lllrll}
\hline $\begin{array}{l}\text { \% area Grade } \\
\text { under peaks }\end{array}$ & $\begin{array}{l}\text { No of } \\
\text { cases }\end{array}$ & Mean & SEM & $p$ \\
\hline $\begin{array}{llrrrr}\text { Peaks } \\
1 \text { and 2 }\end{array}$ & I, II & 19 & 14.11 & 1.25 & \\
& V & 10 & 29.25 & 3.15 & $<0.001$ \\
Peak 1 & I, II & 18 & 2.72 & 0.51 & $<0.005$ \\
& V & 9 & 6.32 & 1.00 & \\
Peak 2 & I, II & 18 & 11.70 & 1.16 & $<0.005$ \\
& V & 9 & 21.70 & 2.80 & \\
\hline
\end{tabular}

Level of significance determined by Student's $t$ test.

When the same analysis was made for the area occupied by peaks 1 and 2 separately (Table 2), the results for grades I and II were $2 \cdot 7 \pm \mathbf{0 . 5 1}$ for peak 1 and $11.7 \pm 1.16$ for peak 2 . In contrast, for grade $V$ specimens the proportional area under peak 1 was $6.32 \pm 1.00$ and for peak $2,21.7 \pm 2.80$. The difference between the peak 1 values was significant $(\mathrm{p}<0.005)$ as also was the difference between the peak 2 values $(p<0.005)$.

Structurally normal cells The combined proportional areas of peaks 1 and 2 from structurally normal cells from all grades were plotted in the form of a scattergram (Fig. 4). It is apparent that these peaks are a higher proportion of the total DNA in the malignant cases than in the normal grades. The results of grades III and IV vary.

When the mean value for the proportional area under peaks 1 and 2 in the normal samples (14.1 


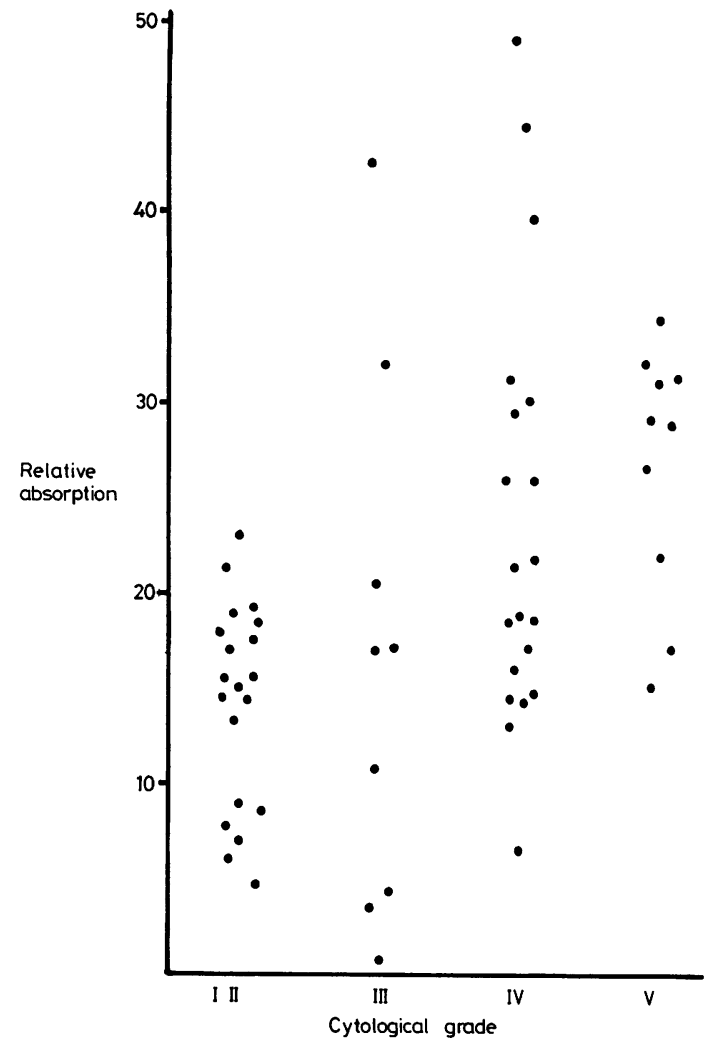

Fig. 4 Scattergram showing the combined proportional area (relative absorption) of peaks 1 and 2 for individual cases plotted against their cytological grade.

Table 3 Cytologically normal cells, from grade $V$ smears, compared with normal cells (from benign cases): the statistical evaluation of the proportional areas occupied by the first two peaks considered together or individually

\begin{tabular}{llllll}
\hline $\begin{array}{l}\text { \% area } \\
\text { under peaks }\end{array}$ & Grade & $\begin{array}{l}\text { No of } \\
\text { cases }\end{array}$ & Mean & SEM & $p$ \\
\hline $\begin{array}{l}\text { Peaks } \\
\text { 1 and 2 }\end{array}$ & I, II & 19 & 14.11 & 1.25 & \\
& V & 10 & 26.55 & 2.19 & $<0.001$ \\
Peak 1 & I, II & 18 & 2.72 & 0.51 & \\
& V & 10 & 5.15 & 0.59 & $<0.005$ \\
Peak 2 & I, II & 18 & 11.70 & 1.16 & $<0.001$ \\
& V & 10 & 21.07 & 1.98 & \\
\hline
\end{tabular}

Level of significance determined by Student's $t$ test.

units $\pm 1 \cdot 25$ ) was compared (Table 3 ) with the mean value for the proportional area of the apparently normal cells in the malignant, grade V samples (26.6 units $\pm 2 \cdot 19$ ), the difference was highly significant in the $t$ test $(\mathrm{p}<0.001)$. The same analysis, made for the area occupied by peak 1 alone, again in apparently normal cells $(2.7 \pm 0.51$ for grade I and II samples and $5.2 \pm 0.59$ for grade $\mathrm{V}$ ), gave a significant difference $(\mathrm{p}<0.005)$, as also did the analysis of peak 2 alone $(11 \cdot 7 \pm 1 \cdot 16$ for grade I and II samples and $21 \cdot 1 \pm 1.98$ for grade $V$ samples; $p<0.001$ ).

\section{Discussion}

The use of Feulgen-hydrolysis profiles clearly differentiates between the malignant (grade $\mathrm{V}$ ) and non-malignant samples on the basis of the lability of the DNA to hydrolysis, as represented by the first and second peaks.

From the results of work done by Solomons 8 it is possible that peak 2 is associated with newlysynthesised DNA since this peak was found in transformed, but not in the untreated, normal lymphocytes. It is assumed that this newlysynthesised DNA, not yet fully incorporated into the tightly-bound chromatin structure, would not be as protected as the stable "original" DNA (peak 3). This view is supported by the work of Trusal et al. ${ }^{7}$ They found that the DNA, newly synthesised as a result of viral infection, was more susceptible to acid hydrolysis than was the original host chromatin.

The "peak 1 DNA" is also present in increased amounts in both "normal" and "positive" cells from some cases of carcinoma-in-situ and dysplasia, although the scattergram (Fig. 3) does show a wide spread of results from both these grades. As it is now generally thought ${ }^{19} 20$ that perhaps no more than one in three cases of carcinoma-in-situ may represent a condition that will progress to invasive cancer, it would be of interest to determine whether there is a correlation between the incidence of a prominent first peak and the potential to progress to invasive cancer.

In summary there are two facets of these results. The first is the finding of a more labile DNA in malignant cells: this may be useful to give functional amplification in a suspect smear. The second is of potentially more practical advantage for the automation of cervical cancer screening. ${ }^{21}$ If the first peak can, in fact, be identified in the cytologically normal cells in a malignant sample, it would not be necessary to search for the often scarce positive cells.

\section{References}

${ }^{1}$ Husain OAN, Millett JA. The detection of malignancy in the cervix. In: Pattison JR, Bitensky L, Chayen J, eds. Quantitative cytochemistry and its applications. London and New York: Academic Press, 1979:231-9.

${ }^{2}$ Millett JA, Chin Y, Bitensky L, Chayen J, Husain OAN. Lysosomal naphthylamidase activity as a possible aid in cytological screening. J Clin Pathol 1980;33:684-7.

${ }^{3}$ Paul J, Gilmour RS. Organ specific restriction of tran- 
scription in mammalian chromatin. $J$ Mol Biol 1968;34: 305-16.

${ }^{4}$ MacGillivray AJ. Non-histone nuclear proteins as gene regulators? Biochem Soc Trans 1976;4:967-78.

${ }^{5}$ Agrell I, Bergqvist H. Cytochemical evidence for varied DNA complexes in the nuclei of undifferentiated cells. J Cell Biol 1962;15:604-6.

6 Bohm N, Sandritter W. Feulgen hydrolysis of normal cells and mouse ascites tumour cells. J Cell Biol 1966;28:1-7.

7 Trusal LR, Anthony A, Docherty JJ. Differential Feulgendeoxyribonucleic acid hydrolysis patterns of herpes simplex virus type 1 and type 2 infected cells. $J$ Histochem Cytochem 1975;23:283-8.

${ }^{8}$ Solomons JR. Cellular biological studies of human breast tumours and the possible influence of steroid hormones. University of London: PhD Thesis, 1978.

${ }^{9}$ Feulgen R, Rossenbeck H. Mikroskopischchemische Nachweiss einer Nukleinsäure vom Typus Thymusmucleinsäure und die darauf beruhende elektive Farbung von Zellkonan in mikroskopischen Proparaten. Z Physiol Chem 1924;135:203-48.

${ }^{10}$ Garcia AM. Studies on DNA in leukocytes and related cells of mammals: VI. The Feulgen-DNA content of rabbit leukocytes after hypotonic treatment. $J$ Histochem Cytochem 1969;17:47-55.

${ }^{11}$ Rasch RW, Rasch EM. Kinetics of hydrolysis during the Feulgen reaction for deoxyribonucleic acid: a reevaluation. J Histochem Cytochem 1973;21:1053-65.

12 Duijndam WAL, Van Duijn P. The influence of chromatin compactness on the stoichiometry of the Feulgen-Schiff procedure studied on model films. II. Investigations on films containing condensed or swollen chicken erythrocyte nuclei. J Histochem Cytochem 1976;23:891-900.
${ }^{13}$ Zelenin AV, Keschch AA, Chebanu TA. Peculiarities of cytochemical properties of cancer cells as revealed by study of deoxyribonucleoprotein susceptibility to Feulgen hydrolysis. J Histochem Cytochem 1977;25: 580-4.

${ }^{14}$ Fukuda N, Bohm N, Fujita S. Errors in absorbance cytophotometry. Prog Histochem Cytochem 1978;11:12-24.

${ }^{15}$ De Cosse JJ, Aiello N. Feulgen hydrolysis: effect of acid and temperature. J Histochem Cytochem 1966;14:601-4.

${ }^{16}$ Davis HJ. Irrigation smear: accuracy in detection of cervical cancer. Acta Cytol 1962;6:459-67.

17 Papanicolaou GN. A new procedure for staining vaginal smears. Science 1942;95:432.

${ }^{18}$ Bitensky L, Butcher RG, Chayen J. Quantitative cytochemistry in the study of lysosomal function. In: Dingle JT, ed. Lysosomes in biology and pathology, 3. Amsterdam: North Holland, 1973:465-510.

${ }^{19}$ Coppleson CW, Brown B. Observations on a model of the biology of carcinoma of the cervix; a poor fit between observations and theory. Am J Obstet Gynecol 1975;126: 127-36.

${ }^{20}$ Kinlen LJ, Spriggs AI. Women with positive cervical smears but without surgical intervention. Lancet 1978 ;ii: 463-5.

21 Millett JA, Husain OAN. Analysis of chromatin in carcinoma-in-situ. In: Pattison JR, Bitensky L, Chayen J, eds. Quantitative cytochemistry and its applications. London and New York: Academic Press, 1979:37-42.

Requests for reprints to: Dr OAN Husain, Department of Cytopathology, Charing Cross Hospital, Fulham Palace Road, London W6 8RF, England. 